\title{
TRAINING OF SCIENCE LITERACY SKILLS IN CHEMICAL EQUILIBRIUM THROUGH IMPLEMENTATION GUIDED INQUIRY LEARNING
}

\author{
Ragil Triyani ${ }^{1}$ and Utiya Azizah ${ }^{1^{*}}$ \\ ${ }^{1}$ Department of Chemistry, Faculty of Mathematics and Natural Sciences, Universitas \\ Negeri Surabaya, Jl. Ketintang Kecamatan Gayungan, Surabaya, 60231, Indonesia \\ *E-mail: utiyaazizah@unesa.ac.id
}

Received: 25 March 2020; Accepted: 20 April 2020; Published: 30 June 2020

\begin{abstract}
Science literacy is the main key to face challenges in the $21^{\text {st }}$ century. The research aimed to describe the students' science literacy on chemical equilibrium topic through implementation of guided inquiry learning model. The research design used is One-Group Pretest-Posttest Design. The research was conducted in class XI MIPA 4 of SMAN 3 Surabaya. Data obtained by instruments of multiple-choice tests of science literacy and observation sheet. The result showed that every aspect of students' science literacy skills was increased in the medium criteria, it was indicated by an average gain score of 0.6 for competence to explain scientific phenomena and to evaluate data and design scientific investigations. Moreover competence of interpreting data and scientific evidence obtained gain score of 0.7 . The result of this research indicated that the skill of science literacy had been trained to students.
\end{abstract}

Keywords: science literacy, chemical equilibrium, guided inquiry learning

DOI: https://doi.org/10.15575/jtk.v5i1.7550

\section{INTRODUCTION}

Chemistry has the same characteristics as science, in the form of the object, how to obtain, and their uses. Science has three main elements, which called science as a scientific attitude, science as a scientific product, and science as a scientific process (Toharudin et al., 2011). Significance in learning chemistry is obtained when students have good science literacy skills. Students need to be trained in science literacy skills in learning so that they expertise connecting concepts with the process that occurs. The statement is in accordance with the research findings that science literacy is a task of both formal and informal science education; it creates a demand for all professionals to become both science literacy participants and educators (Liu, 2009). Other than that, learning chemistry requires meaningful learning that connects with daily life to prepare students who are able to think critically, logically, and creatively so that chemical matters are easier understood and applied in life (Yanni \& Azizah, 2018). Hopefully, they can be applied to make a decision in solving problems in daily life.

The Organization for Economic Co-operation and Development (OECD) (2017) describes science literacy as the skill to use scientific knowledge to identify questions, obtain new knowledge, explain scientific phenomena, and draw conclusions based on scientific evidence related to scientific issues. OECD launched the triennial survey of 15 years old students around the world known as the Program for International Students Assessment (PISA). PISA offers insight for education policy and practice. It helps monitor trends in student's knowledge and skill across countries and in different demographic subgroups within each 
country (OECD, 2018). There are four aspects of science literacy determined by PISA, namely aspects of context, knowledge, attitudes, and competencies. The scientific competence aspect that measured in science literacy skills are (1) explaining phenomena scientifically, (2) evaluating and designing investigations, and (3) interpreting scientific data and evidence. In measuring three science literacy competencies, knowledge is needed. The first competency, explaining the phenomenon scientifically, requires knowledge of the nature of science. The second and third competencies require more than knowledge of what is known, but also depend on understanding how scientific knowledge is constructed from self-confidence. Recognizing and identifying phenomena to fit the characteristics of scientific inquiry requires knowledge of standard procedures that underlie the various methods and practices used to develop science. Ultimately, these competencies require epistemic knowledge, which is a rational understanding to carry out scientific investigations, interpret scientific data and the meaning of basic terms such as theories, hypotheses, and data. Science literacy assessment is not an assessment of context but it assesses competence and knowledge in a particular context (Wang et al., 2019).

Based on the result of a survey conducted by Murti et al. (2018) showed that the percentage of science literacy skill of high school students in Indonesia was $57.14 \%$. This number was lower than the average percentage of science literacy of students in the USA which is around $59.60 \%$. Likewise, the results of the preresearch data carried out at SMAN 3 Surabaya in class XII MIPA 4 and XII MIPA 5 can be seen that the science literacy skills of students in three science literacy competencies included explaining scientific phenomena, evaluating and designing scientific investigations, and interpreting data and scientific evidence obtained a percentage of $6.08 \%, 3.95 \%$, and $7.41 \%$. The low percentage results indicated that students still have limited skill to apply three science literacy competencies. It means that the literacy skill of students can be categorized in low level. It was found that only a small proportion of students were able to use content knowledge, procedural knowledge, and epistemic knowledge to provide explanations, evaluate and design scientific questions, and interpret data from various phenomena in daily life. This situation must be quickly resolved. Based on Pratiwi et al. (2019), to face learning in the $21^{\text {st }}$ century, each student must be trained in digital literacy skills, information literacy, media literacy and also master information and communication technology. By applying the concept of chemistry in science education, Indonesian students are expected to be able to solve problems in real life in this $21^{\text {st }}$-century era by training students' science literacy skill.

Some factors can influence low science literacy skills of students. The first, it is influenced by natural science learning which is still conventional and focuses on reading skills and abilities needed by each student. Second, the student's skill to interpret data in the form of graphs or tables is still low because it can't be relied on; usually students are only assigned to fill the tables that have been provided by the teacher, so that their skill to interpret graphs or tables is still limited. Third, students do not practice working on literacy test questions. Some of these factors indicate that learning process in schools that are very supportive of student's literacy (Anggraini, 2014).

Based on the pre-research questionnaire conducted at SMAN 3 Surabaya, $84 \%$ of students said the chemical equilibrium material, especially in the sub-factors that influence the shift in the direction of equilibrium, is difficult to understand, because it is more often delivered by the lecture method. The difficulty in understanding the material is also an evident from the result of students' science literacy test in the Preresearch which showed that only a few students were able to master three science literacy competencies. It means that the learning process of chemistry had not yet led to learning based on science literacy because students had not been given the space to develop their attitudes, knowledge, and skills. $72 \%$ of students expected to learn using practical work on chemical equilibrium materials, with the hope that the learning 
process was more meaningful if it was in accordance with the wishes of the students.

The chemical equilibrium material contained in Permendikbud No 24, 2016, on basic competencies 3.9 and 4.9 requires an investigation so that students can apply the concepts they have acquired in a practice and relate them to phenomena that exist in daily life. To achieve basic competencies in the chemical equilibrium matter, students are expected to be able to carry out an inquiry process from designing, conducting, to concluding and presenting the results of their investigation. Through investigations about chemical equilibrium, students are expected to be able to fulfill their curiosity and practice their learning independently so they will find out what factors that influence the shift direction in chemical equilibrium reaction. In addition, by conducting learning through student investigations it will be easier to understand and remember what conclusions obtained in the activities, in other words, the learning carried out is more meaningful. This is in accordance with the characteristics of the guided inquiry learning model, which is basically gives time for students to find out an outcome through investigation. The description is in accordance with the finding of the research Aristina and Azizah (2018), states that the guided inquiry learning model can be applied to teach the chemical equilibrium matter in class XI.

Based on Permendikbud No 22, 2016, to strengthen the scientific approach, it is necessary to apply discovery-based learning and inquiry learning which focuses on students. The learning models recommended by the 2013 curriculum and it is relevant to science literacy and also can be applied to learn about chemical equilibrium topic. It is the guided inquiry learning model. In the guided inquiry learning model, students will be encouraged to develop their intellectual and skills through their curiosity. Students will be faced with a problem in which phenomena are taken from daily life so that students at the same time know the form of implementation of chemistry in their lives.
The guided inquiry model emphasizes awareness and mastery of the investigation process rather than the content of a particular problem situation. This model invites students to realize the investigation process as something that needs to be done seriously, the skill is contributed to exploring data, making and testing hypotheses, and producing new discoveries that are original and creative. The main learning outcomes of this learning model are processes that involve observation activities, collecting and processing data, identifying and controlling variables, making and testing hypotheses, formulating explanations and drawing conclusions (Joyce et al., 2011). This is in line with science literacy, where science literacy not only requires knowledge of scientific concepts and theories but also requires knowledge of procedures and exercises related to scientific inquiry and how to enable the science to progress (OECD, 2017). This opinion is also reinforced by the results of research Mc Conney et al. (2014) states that guided inquiry learning is oriented towards inquiry enables students to have higher scientific literacy skills and positively influences science, and McCright (2012) that guided inquiry learning is more effective in increasing the student's scientific literacy.

The syntaxes of guided inquiry learning model are presenting problems or phenomena, collecting evidentiary or verification data, collecting experimental data, organizing and formulating explanations, and also analyzing the investigation process (Joyce et al., 2011). The main purpose of guided inquiry learning model is to give students experience in taking the initiative to determine the problem, then discuss or formulate and recommend a policy to solve the problem.

\section{RESEARCH METHOD}

The type of this research was "preexperimental Design" that only given to one study group without control's group as comparison. The research involves 32 students class XI MIPA 4 at SMAN 3 Surabaya during 2019/2020. The design of this research was "One-Group Pretest-Posttest Design" by 
giving pretest before learning process and posttest after learning process (Sugiono, 2015). It can be described as:

\section{$\mathbf{O}_{1} \times \mathbf{O}_{2}$}

Note:

$\mathrm{O}_{1} \quad=$ Pretest value of science literacy skill (before guided inquiry learning applied)

$X \quad=$ Treatment with guided inquiry learning model

$\mathrm{O}_{2} \quad=$ Posttest value of science literacy skill (after guided inquiry learning applied)

This research used lesson plans and worksheets. Instruments used in this research are observation sheets of teacher's activities and student's activities and Pretest-Posttest science literacy test sheet. This research was carried out through three stages of implementation including the preparation stage, the implementation stage, and the final stage. Data were collected by observation and test methods (Sugiono, 2015). Data value of science literacy skill was calculated by the gain score. The value of science literacy was calculated for each competency. The gain score can be calculated by the formula:

$$
<g>=\frac{\%<G>}{\%<G>_{\text {maks }}}=\frac{\% S f-\% S i}{100-\% S i}
$$

(Hake, 1999)

Note:

$\mathrm{Sf}=$ Posttest score

$\mathrm{Si}=$ Pretest score

The number obtained, then converted to the gain level criteria on Table 1.

Table 1. Gain Level Criteria

\begin{tabular}{|c|c|}
\hline Score & Criteria \\
\hline$(<\mathrm{g}>)>0,7$ & High \\
\hline $0,7 \geq(<\mathrm{g}>) \geq 0,3$ & Medium \\
\hline$(<\mathrm{g}>)<0,3$ & Low \\
\hline \multicolumn{2}{|c|}{ (Hake, 1999) } \\
\hline
\end{tabular}

\section{RESULT AND DISCUSSION}

The development of students' science literacy skill is known through the provision of Pretest and Posttest question about chemical equilibrium topic. The test was done individually. Students answered 10 items multiple-choice questions. Multiple choice instruments are usually used in standardized tests on a broad scale (Martin \& Itter, 2014). Multiple choice questions were composed of two parts: a stem and a set of possible answers. Students responded to question based on issues or phenomena in stem and the functioning of deceptive answers based on science literacy in multiple-choice reasons that made students were not easy to answer questions and trained students to think more in answering questions. The questions that were tested also included 4 questions of aspects of content knowledge, 3 questions of aspects of procedural knowledge and 3 questions of aspects of epistemic knowledge $\bar{T}_{\bar{T}}$ The score of each question is 1 if it is answered correctly, while it is given 0 if the answered is blank or incorrect.

The aim of giving a Pretest was to know the student's initial science literacy skill, while the purpose of giving a Posttest was to know the student's science literacy skill after the implementation of guided inquiry learning models on chemical equilibrium matter. Furthermore the results of Pretest and Posttest questions that were tested to students in accordance with basic competence 3.9 which is listed in Permendikbud No 24, 2016, analyzing the factors that influence the shift direction of equilibrium applied in the industry.

The Pretest and Posttest questions tested were included in the C4 cognitive level (analyzing). At the level of analysis, the expected output is to sort information into more detailed units so that a function or relation to a larger part can be known. Students are expected to be able to analyze information received to analyze patterns or correlations (Darmawan \& Sujoko, 2013).

Pretest and Posttest were conducted outside the hours of chemistry lessons. The topic was used as pretest and posttest material is chemical equilibrium specifically sub matter factors that affect the shift direction of 
Training of Science Literacy Skills in Chemical Equilibrium Through Implementation Guided Inquiry Learning

chemical equilibrium reaction. A total of 10 number reasoned multiple-choice items tested included concentration factors, temperature factors, and pressure and volume factors. The questions consist of four questions related to aspects of scientific explaining competency (items number 1, 2, 5, and 8 on Pretest sheet and items number 1,4 , 5,8 on Posttest sheet), three questions related to competency aspects of evaluating and designing scientific investigations (items numbers 3, 6, and 9 on Pretest sheet and items number 3, 7, and 10 on Posttest sheet), and three questions related to competency aspects of interpreting scientific data and evidence (items number 4, 7, and 10 on Pretest sheet and items number 3,7 , and 10). Time for doing question given is 30 minutes.

The Pretest and Posttest values that have been obtained were tested normality first using the Shapiro Wilk Method because the sample used is less than 50 samples. The purpose of the normality test is to assess the distribution of a group of data or find information on whether the variables are normally distributed can be assumed that the sample used truly represents a population so that later research results obtained can be generalized to the population.

The Shapiro Wilk test shows the best normal distribution results for small samples followed by the Lilliefor and Kolmogorov-Smirnov tests (Oktaviani \& Notobroto, 2014). The normality test result of the Pretest and Posttest data were presented in Table 2.

Table 2. The Results of Normality Test

\begin{tabular}{|l|c|c|c|c|c|c|}
\hline & \multicolumn{3}{|c|}{ Kolmogorov-Smirnov } & \multicolumn{3}{|c|}{ Shapiro-Wilk } \\
\cline { 2 - 7 } & Statistic & $\mathrm{df}$ & Sig. & Statistic & $\mathrm{df}$ & Sig. \\
\hline $\begin{array}{l}\text { POSTTEST } \\
\text { LITERASI SAINS }\end{array}$ & 0.159 & 32 & 0.38 & 0.938 & 32 & 0.067 \\
\hline $\begin{array}{l}\text { PRETEST } \\
\text { LITERASI SAINS }\end{array}$ & 0.151 & 32 & 0.062 & 0.940 & 32 & 0.077 \\
\hline
\end{tabular}

Normality test results indicated that the Pretest value data has a significance level of 0.007, it means that the data values obtained are normally distributed. Posttest value data has a significance level of 0.067 , it means that the data obtained are also normally distributed.
The Pretest and Posttest results of science literacy of students in each aspect of competence were described as follows.

\subsection{The competence aspect of explaining phenomena scientifically}

Data on the results of the pretest and posttest competencies explaining phenomena scientifically are presented in Figure 1.

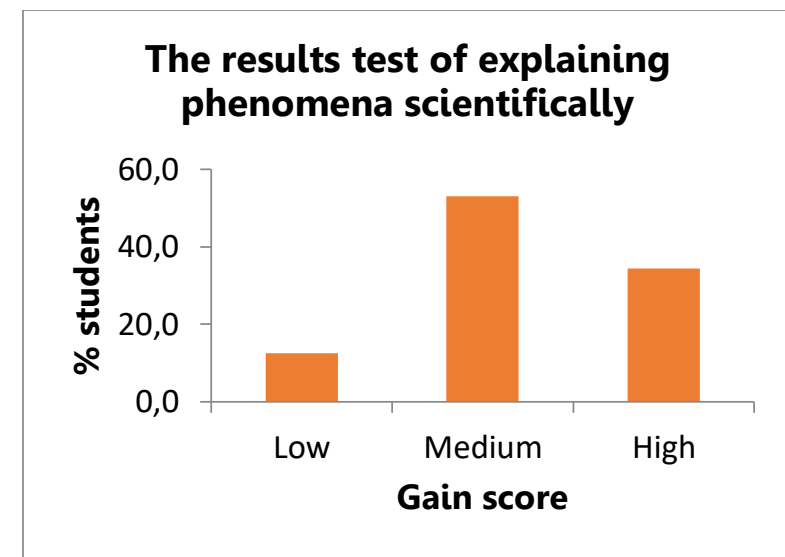

Figure 1. The Result Test of Explaining Phenomena Scientifically

Based on the results of Figure 1, students after getting the chemical equilibrium material using the guided inquiry learning model, the pretest and posttest scores were increased. Improving student's science literacy skill was calculated with a gain score with a result as 0.6 that included in the medium criteria. These results proved that by applying the guided inquiry learning model to chemical equilibrium material, the student's science literacy skill to explain phenomena scientifically had been trained when the learning process worked on exercises and experiments in students' worksheets so that they could understand and answer the Posttest question given. The findings of this study were consistent with the results of the study that students' science literacy skills can be optimized through the application of learning based on experiment activities (Irmita \& Atun, 2017).

The increasing in gain score also showed that $12.5 \%$ of students were in the low criteria, $53.1 \%$ of students were in the medium criteria, and $34.4 \%$ of students were in the high criteria. 
It showed that most students already have the skill to explain scientific phenomena. By having the skill to explain phenomena scientifically, students could understand chemical materials that have relevance to daily life. This is in accordance with the research's result that teacher makes them easy to understand about chemical equilibrium matter by giving phenomena (Rahayu, 2017).

There are four questions about competence to explain scientific phenomena that were given to students. The first item deals with the phenomenon of the $\mathrm{NO}_{2}$ and $\mathrm{N}_{2} \mathrm{O}_{4}$ equilibrium reactions that are influenced by the pressure in the system. In the first item, students were asked to be able to determine the right reaction equation based on the phenomenon. In the Pretest, there were 17 students who were able to answer correctly, while in the Posttest 21 students could answer the questions correctly. The second item concerned the phenomenon of tooth enamel equilibrium which causes the enamel layer to become porous due to the addition of an acid from food. In the second problem, students were expected to be able to determine the exact equation of reaction based on the phenomenon. At Pretest, the results showed that only 6 students were able to answer the question correctly, while at Posttest 31 students answered the question correctly. The third item was still related to the phenomenon of tooth enamel equilibrium. In the third question students were asked to determine the appropriate writing of appropriate equilibrium constant for the reaction. The results of the Pretest showed that 5 students were able to answer the questions correctly, while at Posttest 13 students successfully answered questions correctly. The fourth item concerned the phenomenon of the equilibrium reaction of making ammonia gas from nitrogen gas and hydrogen gas. Learners were asked to determine the equilibrium constant reaction for the ammonia gas manufacture. At the Pretest, there were 17 students who were able to answer correctly, while at the Posttest as many as 32 students could answer the questions correctly.

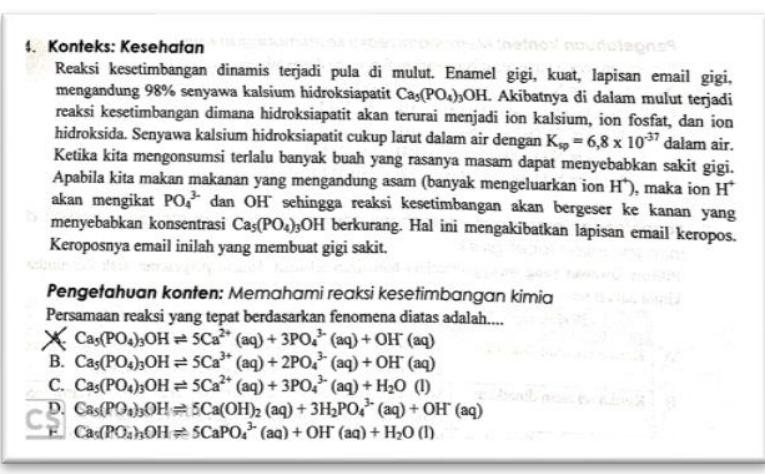

Figure 2. The Correct Answer of Student on Explaining Phenomena Scientifically Test

Reaksi kesetimbangan dinamis terjadi pula di mulut. Enamel gigi, kuat, lapisan email gigi, mengandumg $98 \%$ senyawa kalsium hidroksiapatit $\mathrm{Ca}_{5}\left(\mathrm{PO}_{4}\right)_{3} \mathrm{OH}$. Akibatnya di dalam mulut terjadi reaksi kesetimbangan dimana hidroksiapatit akan terurai menjadi ion kalsium, ion fosfat, dan ion hidroksida. Senyawa kalsium hidroksiapatit cukup larut dalam air dengan $\mathrm{K}_{\mathrm{sp}}=6,8 \times 10^{-37}$ dalam air. Ketika kita mengonsumsi terlalu banyak buah yang rasanya masam dapat menyebabkan sakit gigi. Apabila kita makan makanan yang mengandung asam (banyak mengeluarkan ion $\mathrm{H}^{*}$ ), maka ion $\mathrm{H}^{+}$akan mengikat $\mathrm{PO}_{4}{ }^{3}$ dan $\mathrm{OH}^{-}$sehingga reaksi kesetimbangan akan bergeser ke kanan yang menyebabkan konsentrasi $\mathrm{Ca}_{5}\left(\mathrm{PO}_{4}\right)_{3} \mathrm{OH}$ berkurang. Hal ini mengakibatkan lapisan email keropos. Keroposnya email inilah yang membuat gigi sakit.

Pengetahuan konten: Memahami reaksi kesetimbangan kimia Persamaan reaksi yang tepat berdasarkan fenomena diatas adalah....

A. $\mathrm{Ca}_{5}\left(\mathrm{PO}_{4}\right)_{3} \mathrm{OH} \rightleftharpoons 5 \mathrm{Ca}^{2+}$ (aq) $+3 \mathrm{PO}_{4}{ }^{3-}$ (aq) $+\mathrm{OH}$ (aq)

B. $\mathrm{Ca}_{5}\left(\mathrm{PO}_{4}\right)_{3} \mathrm{OH} \rightleftharpoons 5 \mathrm{Ca}^{3+}$ (aq $)+2 \mathrm{PO}_{4}{ }^{3-}(\mathrm{aq})+\mathrm{OH}(\mathrm{aq})$

Q. $\mathrm{Ca}_{5}\left(\mathrm{PO}_{4}\right)_{3} \mathrm{OH} \rightleftharpoons 5 \mathrm{Ca}^{2+}$ (aq) $+3 \mathrm{PO}_{4}{ }^{3-}$ (aq) $+\mathrm{H}_{2} \mathrm{O}$ (l)

C. $\mathrm{Ca}_{5}\left(\mathrm{PO}_{4}\right)_{3} \mathrm{OH} \rightleftharpoons 5 \mathrm{Ca}(\mathrm{OH})_{2}(\mathrm{aq})+3 \mathrm{H}_{2} \mathrm{PO}_{4}{ }^{3 \cdot}$ (aq) $+\mathrm{OH}$ (aq)

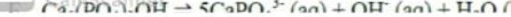

Figure 3. The Wrong Answer of Student on Explaining Phenomena Scientifically Test

\subsection{The competence aspect of evaluating and designing investigations}

Data on the result of the pretest and posttest competencies evaluating and designing investigations were presented in Figure 4.

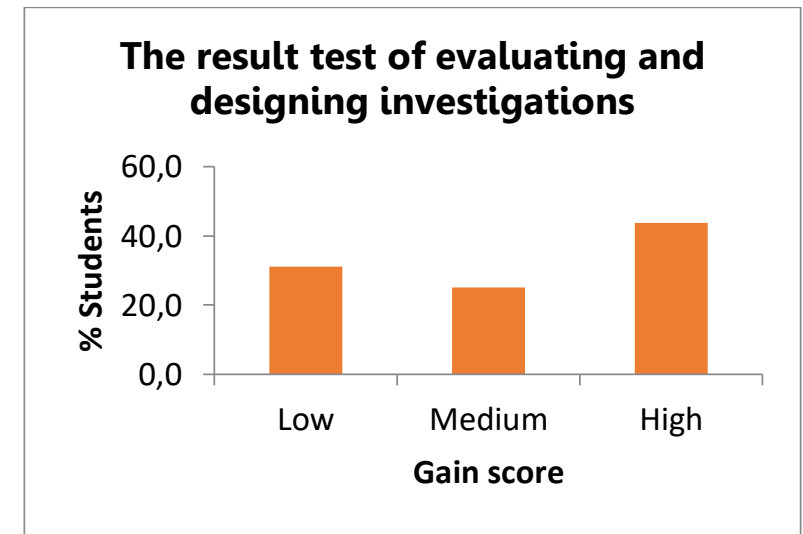

Figure 4. The Results Test of Evaluating and Designing Investigations

Jurnal Tadris Kimiya 5, 1 (Juni 2020): 35-47 
Based on graph in Figure 4, most of students had high gain score. It showed that after learning chemical equilibrium using guided inquiry learning models, they increased their value of Posttest. Increasing students' science literacy skill was calculated with a gain score with a result of 0.6 included in the medium criteria. These results proved that applying the guided inquiry learning model in chemical equilibrium material, the evaluation and design scientific investigations competence has been trained when the learning process of doing exercises and experiments in the worksheets so that they understand and can work on the Posttest questions given.

The increasing in gain score also showed that $31.2 \%$ students were in the low criteria, $25 \%$ students were in the medium criteria, and $43.8 \%$ students were in the high criteria. It showed that most students already have the skill to evaluate and design investigations. This result of research is relevant with the study that giving space to find learning experiences for students will better help students understand mastery of concepts (DarlingHammond et al., 2020).

Competence of evaluating and designing scientific investigations related to procedural knowledge, i.e. knowledge of empirical inquiry relies on existing concepts, such as ideas about measurement types, dependent and independent variables, control variables, inaccuracies, general patterns observed, methods for minimizing errors, and data presentation methods. Knowledge of these concepts and procedures is important for scientific inquiry $(O E C D, 2017)$.

There were three questions about the competence of evaluating and designing scientific investigations given to students. The first item deals with the phenomenon of $\mathrm{NO}_{2}$ and $\mathrm{N}_{2} \mathrm{O}_{4}$ gas equilibrium reactions that are influenced by the pressure in the system. The problem was given with instructions regarding the color of $\mathrm{NO}_{2}$ and $\mathrm{N}_{2} \mathrm{O}_{4}$ gas, besides that the problem was also given with color change images so that students will be easier to analyze the phenomena presented. In the first item of competence evaluating and designing scientific investigations, students were asked to determine the effect of a treatment to the system on the shift direction of chemical equilibrium which is characterized by changes in the color of the solution. In the Pretest, 13 students could answer question correctly, while in the Posttest 26 students could answer it. The second item concerned the phenomenon of tooth enamel equilibrium which causes the enamel layer to become porous due to the addition of an acid from food. Hydroxyapatite compound, $\mathrm{Ca}_{5}\left(\mathrm{PO}_{4}\right)_{3} \mathrm{OH}$, contained in tooth enamel. The compound was quite soluble in water with its $\mathrm{Ksp}$ as $6.8 \times 10^{-37}$. In the second question, students were asked to determine the effect of a treatment on shift direction of chemical equilibrium which is characterized by the loss of tooth enamel. At Pretest, the results showed that only 20 students could answer the question correctly, while at Posttest 30 students answered the question correctly. The third item concerned the phenomenon of the equilibrium reaction of making ammonia gas from nitrogen and hydrogen gas. In this problem, teacher gave data about the reaction equation, the magnitude of enthalpy of ammonia-making reaction $(\Delta \mathrm{H}=-92.4 \mathrm{~kJ})$, and data on the temperature relationship with the equilibrium constant in tabular form. Students were asked to determine and analyze the effect of temperature changes on the shift direction in chemical equilibrium reactions. At Pretest, there were no students who were able to answer correctly, while at Posttest 16 students could answer the question correctly. Students still found difficulties in answering this problem because the concept of exothermic and endothermic reactions possessed by some students was still not strong so they seemed rather confused in understanding the concept of the temperature factor to answer this problem. It is in accordance with study which states that content knowledge obtained by students previously is needed to build new knowledge of students (Rice \& Kitchel, 2016). 


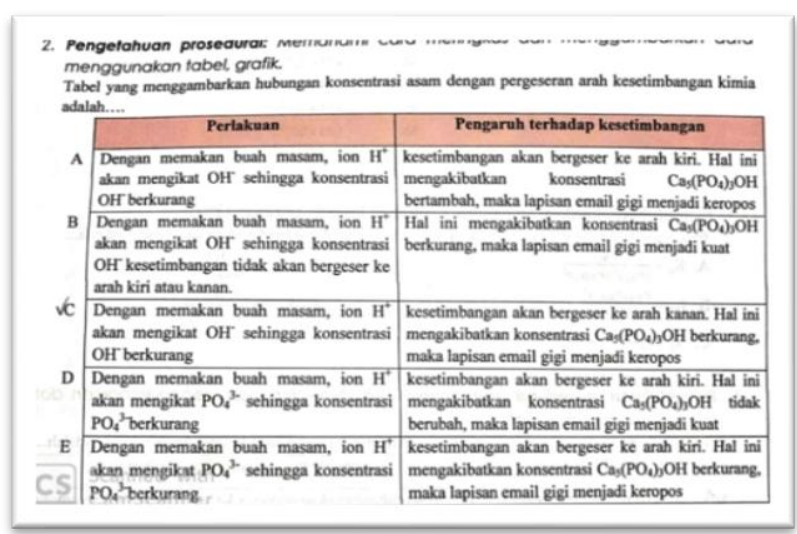

Figure 5. The Correct Answer of Students on Evaluating and Designing Investigation's Test

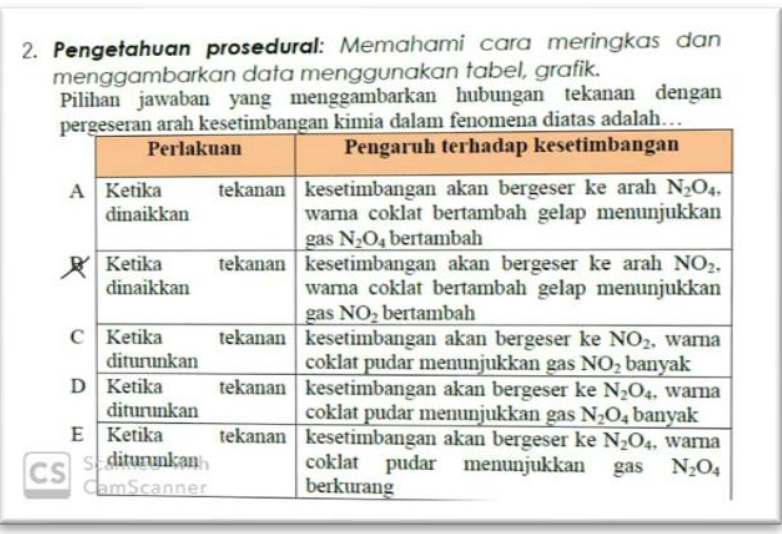

Figure 6. The Wrong Answer of Students on Evaluating and Designing Investigation's Test

\subsection{The competence aspect of interpreting data and scientific evidence}

Data on the results of the pretest and posttest competencies interpreting data and scientific evidence are presented in Figure 7.

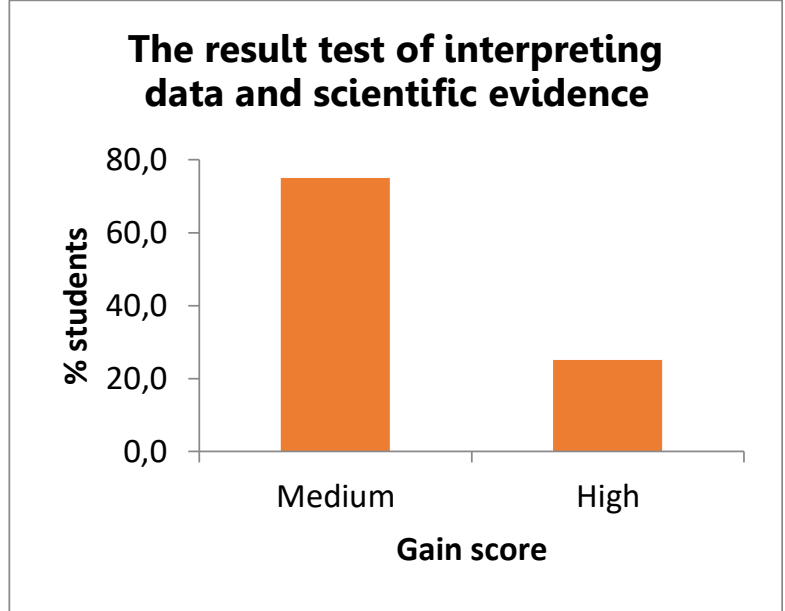

\section{Figure 7. The Results Test of Interpreting Data and Scientific Evidence}

Based on the graph in Figure 7, most student got medium gain score criteria. It showed that the initial student's science literacy skill especially in aspects of competence in interpreting data and scientific evidence was still very low. After having the chemical equilibrium topic using guided inquiry learning model students' literacy skills on these aspects was increased. Improving student's science literacy skill was calculated by a gain score obtained results as including high criteria. These results proved that by applying the guided inquiry learning model to chemical equilibrium topic, the science literacy skill of students to interpret data and scientific evidence had been trained so that they comprehended and can work on the Posttest question given. Students were given three questions regarding competence in interpreting data and scientific evidence in the form of multiple choice questions. The result of increasing the skill to interpret data and scientific evidence in this study were consistent with research which states that by applying guided inquiry learning will give students space to practice to interpret data so that their skill increased (Arief, 2015).

According to PISA 2015, the activity of interpreting data and scientific evidence begins with looking for patterns, making tables and visualizing in the form of diagrams in the form of scatter, bar, circle, Venn, and even bar charts. If data is complicated, data processing can be assisted with the use of 
analytical tools, but this competency requires substantial knowledge in the form of epistemic knowledge to distinguish between hypotheses with theories or scientific facts and observations.

The increasing in gain score also showed that $75 \%$ students were in the medium criteria, and $25 \%$ students were in the high criteria. It showed that most students already had the skill to interpret data and scientific evidence. The increasing occurred significantly because at the time of the Pretest, most students still had difficulty to interpret data so that after learning use the guided inquiry learning model their Posttest scores had increased quite significantly. This result was consistent with the previous result study that a significant difference in the increase of students science literacy who take guided inquiry learning with students who take traditional learning or lectures is very clear (Puspitasari, 2015).

Students were given three questions regarding competence in interpreting data and scientific evidence in the form of multiple choice questions. The first item presented an experimental phenomenon to prove a claim that changing the pressure on the system shifts equilibrium toward substances that have smaller moles by using deductive logic. In the questions presented some experimental data, students were asked to determine which experimental data were in accordance with the deductive logic. In the Pretest, there were 7 students who were able to answer correctly, while in the Posttest 30 students could answer the question correctly. The second item concerned the phenomenon of experiments to prove the claim that adding the same ions to the reactants will shift the equilibrium toward the product. The logic in this experiment used inductive logic. The experiment was carried out by reacting $10 \mathrm{~mL} \mathrm{FeCl}_{3} 0.01 \mathrm{M}$ with $10 \mathrm{~mL}$ KSCN $0.01 M$, then presented several statements of the results of experiment with the addition of $\mathrm{KSCN}_{1} \mathrm{FeCl}_{3}, \mathrm{AgNO}_{3}$, and Aquadest. Students were asked to analyze which statements support the scientific claim that adding the same ions to reactants will shift equilibrium toward the product. At the Pretest, the results showed that only one student was able to answer the question correctly, while at the Posttest 13 students answered the question correctly. The third item about the phenomenon of experiments to prove scientific claims that changes in temperature in the system will shift the chemical equilibrium. The logic used deductive logic. The experiment was carried out by mixing $2 \mathrm{~mL} \mathrm{CuSO}_{4}$ with 1 grams $\mathrm{NaCl}_{\text {, }}$ then heated to a certain temperature. Some problem statements of experimental observations were presented. Students were asked to determine which statements support the scientific claim based on deductive logic. At the Pretest, there were no students who were able to answer correctly, while at the Posttest 28 students could answer the question correctly.

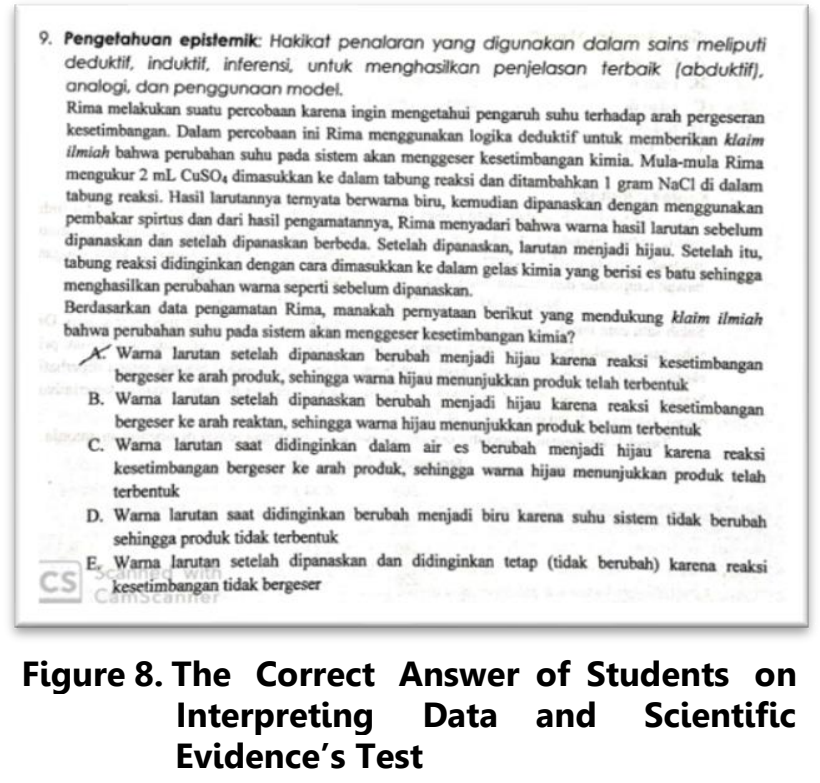

Jurnal Tadris Kimiya 5, 1 (Juni 2020): 35-47 


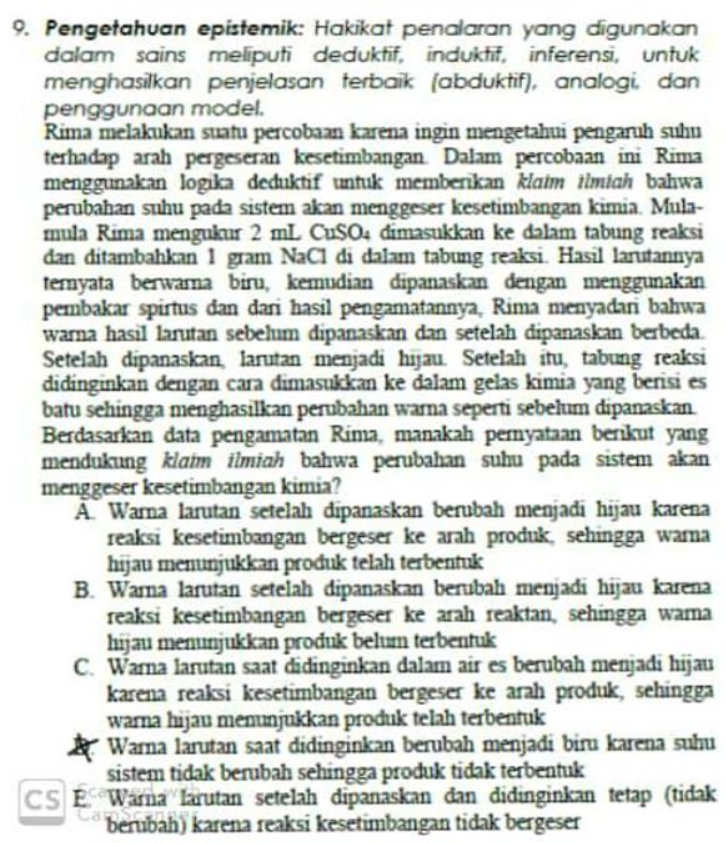

9. Pengetahuan epistemik: Hakikat penalaran yang digunakan dalam sains meliputi deduktif, induktif, inferensi, untuk menghasilkan penjelasan terbaik (abduktif), analogi dan penggunaan model.

Rima melakukan suatu percobaan karena ingin mengetahui pengaruh sulwu terhadap arah pergeseran kesetimbangan. Dalam percobaan ini Rima menggunakan logika deduktif untuk memberikan klaim timiah bahwa perubahan suhu pada sistem akan menggeser kesetimbangan kimia. Mula mula Rima mengukur $2 \mathrm{~mL}$ CuSO dimasukkan ke dalam tabung reaksi dan ditambahkan 1 gram $\mathrm{NaCl}$ di dalam tabung reaksi. Hasil larutannya ternyata berwama biru, kemudian dipanaskan dengan menggunakas pembakar spirtus dan dari hasil pengamatannya. Rima menyadan bahwa

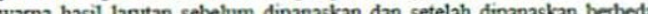

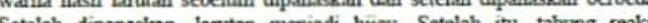
Setelat dipariang reaks didinginkan dengan cara dimasuldean ke dalam gelas kimia yang berisi es batu sehingga menghasilkan perubahan warna seperti sebelum dipanaskan. Berdasarkan data pengamatan Rima, manakah pernyataan berikut yang mendukung klaim ilmiah bahwa perubahan suhu pada sistem akan menggeser kesetimbangan kimia?

A. Warna larutan setelah dipanaskan berubah menjadi hijau karena reaksi kesetimbangan bergeser ke arah produk, sehingga wama hijau menunjukkan produk telah terbentuk

B. Wama larutan setelah dipanaskan berubah menjadi hijan karena reaksi kesetimbangan bergeser ke arah reaktan, sehingga wama hijau menunjukkan produk belum terbentuk

C. Warna larutan saat didinginkan dalam air es berubah menjadi hijau karena reaksi kesetimbangan bergeser ke arah produk, sehingga warna hijas menunjukkan produk telah terbentuk

* Wama larutan saat didinginkan berubah menjadi biru karena suhu sistem tidak berubah sehingga produk tidak terbentuk

E. Warna larutan setelah dipanaskan dan didinginkan tetap (tidak berubah) karena reaksi kesetimbangan tidak bergeser

\section{Figure 9. The Wrong Answer of Students on Interpreting Data and Scientific Evidence's Test}

From the description above, it is known that all three aspects of science literacy competencies have been increased in the low, medium, and high categories. The increasing is due to the different treatment from the previous learning process, namely using the guided inquiry learning model.

The main learning outcomes of guided inquiry learning model are processes that involve observation activities, collecting and processing data, identifying and controlling variables, making and testing hypotheses, formulating explanations, and drawing conclusions. The guided inquiry learning model very well integrates some processing skills into a meaningful learning. Although the emphasis is on the process, the guided inquiry learning model also influences the learning material in all curriculum areas from the point of view of the problem to be chosen. The guided inquiry learning model offers active and autonomous learning, especially when students formulate question and test ideas (Joyce et al., 2011).

The successful application of inquiry learning models in a learning process determines the level of student's understanding of chemical equilibrium matter. In other words, if the application of guided inquiry learning model on chemical equilibrium material is success, then the learning outcomes of students will be good (Handayanti et al., 2016).

Before starting learning, teachers often provide apperception and motivation first. In Advance Organizer learning theory, students do not always know what is important or relevant and many students need external motivation in carrying out the cognitive tasks required to learn what is taught in the school (Basleman \& Mappa, 2011). According to Saifuddin (2015), apperception is used to harmonize existing understanding with newly acquired understanding so that there will be synchronization of students understanding logically, systematically, and structurally. While the purpose of providing motivation is to encourage students to be interested in learning chemical equilibrium matter because many phenomena has related to daily life as an example of chemical equilibrium events. Ernata (2017) states that providing motivation will encourage students to behave in a direction in order to improve learning outcomes better In short, it can be said that giving apperception and motivation aims to stimulate the curiosity of students and raise critical thinking about the phenomena presented. In addition, so students have a picture of the matter obtained previously with new matter to be studied.

The implementation of the guided inquiry learning model was observed by three observers using the teacher's activity observation sheet which observed according to the activity per phase of guided inquiry learning model to ensure that the teacher was in accordance with the prepared lesson plan. In addition, the activities of students during learning process were also observed to determine whether the activity was in accordance with its syntaxes or not. Based on these activities, it could also be determined whether the science literacy skill had been trained to students. Student activity observation sheets were used to observe student's activities during the learning

Jurnal Tadris Kimiya 5, 1 (Juni 2020): 35-47 
process. The activity was observed by three observers every three minutes by observing the dominant activity of each group.

One observer observed two groups, each group consisted of 5-6 people. Student activity categories had been written in the student activity categories sheet. Student activity sheets were made by the researchers and had been validated by two validators who are competent in their fields. Student activities that were appropriate to science literacy include: paying attention when the teacher explained, listening to the teacher's directions, expressing opinions, formulating problem statements, conducting group discussions, compiling hypotheses, determining research variables, conducting experiments and observing the results of experiments, collecting and analyzing experimental data, communicating analysis of experimental results, respond to the presentation of other group results, conclude subject matter, and relate concepts to phenomena.

\section{CONCLUSION}

Based on the result of research conducted in class XI MIPA 4 at SMAN 3 Surabaya, it can be concluded that three aspects of science literacy competencies of students were increased in the medium criteria, which was indicated by an average gain score of 0.6 for competence to explain phenomena scientifically and to evaluate and design scientific investigations competence, while competence of evaluating data and scientific evidence obtained a gain score of 0.7 . This increasing data can be specified, among other for explaining phenomena scientifically competence $12.5 \%$ students were in the low criteria, $53.1 \%$ students were in the medium criteria, and $34.4 \%$ students were in the high criteria. For the competence of evaluating and designing scientific investigations $31.2 \%$ students were in the low criteria, $25 \%$ students were in the medium criteria, and $43.8 \%$ students were in the high criteria. For competence of interpreting data and scientific evidence $75 \%$ students were in the medium criteria and $25 \%$ students were in the high criteria. 
Training of Science Literacy Skills in Chemical Equilibrium Through Implementation Guided Inquiry Learning

\section{REFERENCES}

Anggraini, G. (2014). Analisis Kemampuan Literasi Sains Siswa SMA Kelas X di Kota Solok. Prosiding Matematics and Science Forum 2014, 161-170, Semarang: Universitas PGRI.

Arief, M. K. (2015). Penerapan Levels of Inquiry pada pembelajaran IPA Tema Pemanasan Global Untuk Meningkatkan Literasi Sains. Edusentris: Jurnal Ilmu Pendidikan dan Pengajaran, 2(2), 166-176.

Aristina, \& Azizah, U. (2018). Melatihkan Keterampilan Proses Sains Peserta Didik Melalui Implementasi Model Pembelajaran Inkuiri Terbimbing pada Materi Kesetimbangan Kimia Kelas XI di SMA Negeri 1 Jombang. Unesa Journal of Chemical Education, 7(2) 105-110.

Basleman, A., \& Mappa, S. (2011). Teori Belajar Orang Dewasa. Bandung: PT Raja Rosdakarya.

Darling-Hammond, L., Flook, L., Cook-Harvey, C., Barron, B., \& Osher, D. (2020). Implications for Educational Practice of the Science of Learning and Development. Journal Applied Developmental Science, 24(2), 97-140.

Darmawan, I. A., \& Sujoko, E. (2013). Revisi Taksonomi Pembelajaran Benyamin S. Bloom. Satya Widya, 29(1), 30-39.

Ernata, Y. (2017). Analisis Motivasi Belajar Peserta Didik Melalui Pemberian Reward dan Punishment di SDN Ngaringan 05 Kec. gandusari Kab. Blitar. Jurnal Pemikiran dan Pengembangan SD, 5(2), 781-790.
Hake, R. R. (1999). Interactive-engagement Versus Traditional Methods: ASixThousand-Student Survey of Mechanics Test Date For Introductory Physic Course. American Journal of Physics, 66(1), 66-74.

Handayanti, Y., Sopandi, W., \& Kadarohman, A. (2016). Profil Kemampuan berinkuiri Siswa SMA pada Topik Pengaruh Perubahan Suhu Terhadap Sistem Kesetimbangan Kimia. Jurnal Tadris Kimiya, 1(2), 38-46.

Irmita, L. U., \& Atun, S. (2017). Pengembangan Pembelajaran Menggunakan Pendekatan TPAK untuk Meningkatkan Literasi Sains. Jurnal Tadris Kimiya, 2(1), 84-90.

Joyce, B. R., Weil, M., \& Calhoun, E. (2011). Models of Teaching (8th ed.). USA: Pearson Education Inc.

Kemendikbud. (2016). Permendikbud Nomor 22 Tahun 2016 Tentang Standar Proses Pendidikan Dasar dan Menengah. Jakarta: Mendikbud.

Kemendikbud. (2016). Permendikbud Nomor 24 Tahun 2016 Tentang Kompetensi Inti dan Kompetensi Dasar Pelajaran pada Kurikulum 2013 pada Pendidikan Dasar dan Pendidikan Menengah. Jakarta: Mendikbud.

Liu, X. (2009). Beyond science literacy: Science and the public. International Journal of Environmental and Science Education, 4(3), 301-311.

Martin, D. L., \& Itter, D. (2014). Valuing Assessment in Teacher EducationMultiple-choice Competency Testing, Australian Journal of Teacher Education, 39(7), 1-14. 
Training of Science Literacy Skills in Chemical Equilibrium Through Implementation Guided Inquiry Learning

McCright, A.M (2012). Enhancing students' scientific and quantitative literacies through an inquiry-based learning project on climate change. Journal of the Scholarship of Teaching and Learning, 12(4), $86-102$.

Mc Conney, A. W., Oliver, M. C., Mc Conney, A., Schibeci, R., \& Maor, D. (2014). Inquiry, Engagement, and Literacy in Science: $A$ Retrospective, Cross-National Analysis Using PISA 2006. Science Education, 98(6), 963-980.

Murti, P. R., Aminah, N. S., \& Harjana. (2018). The Analysis of High School Students' Science Literacy Based on Nature of Science Literacy Test (NOSLiT). Journal of Physics: Conference Series, 1097(1).

OECD. (2017). PISA 2015: Technical Report. PISA, Paris: OECD Publishing.

OECD. (2018). PISA 2015 Result in Focus. PISA, Paris: OECD Publishing.

Oktaviani, M. A., \& Notobroto, H. B. (2014). Perbandingan Tingkat Konsistensi Normalitas Distribusi Metode Kolmogorov-Smirnov, Lilliefofrs, Saphiro Wilk, dan Skewness-Kurtosis, Jurnal Biomerika dan Kependudukan, 3(2), 127-135.

Pratiwi, S. N., Cari, C., \& Aminah, S. (2019). Pembelajaran IPA Abad 21 dengan Literasi Sains Siswa, Jurnal Materi dan Pembelajaran Fisika (JMPF), 9(1), 34-42.

Puspitasari, A. D. (2015). Efektivitas Pembelajaran Berbasis Guided Inquiry untuk Meningkatkan Literasi Sains Siswa, OMEGA Jurnal Fisika dan Pendidikan Fisika, 1(2), 1-5.

Rahayu, S. (2017). Mengoptimalkan Aspek Literasi Dalam Pembelajaran Kimia Abad 21. Prosiding Seminar Nasional
Kimia UNY 2017, 1-16, Yogyakarta: FMIPA UNY.

Rice, A.H. \& Kitchel, T. (2016). Influence of Knowledge of Content and Students on Beginning Agriculture Teachers' Approaches to Teaching Content, Journal of Agricultural Education, 57(4), 86-100.

Saifudin, M. F. (2015). Optimalisasi Apersepsi Pembelajaran Melalui Folklor Sebagai Upaya Pembentukan Karakter Siswa Sekolah Dasar. Prosiding Seminar Nasional, 180-185, Surakarta: Universitas Muhammadiyah Surakarta.

Sugiono. (2015). Metode Penelitian Kuantitatif, Kualitatif, dan R\&D. Bandung: Alfabeta.

Toharudin, U., Hendrawati, S., \& Rustaman, A. (2011). Membangun Literasi Sains Peserta Didik. Bandung: Humaniora.

Wang, Y., Lavonen, J., Tirri, K. (2019). An assessment of How Scientific LiteracyRelated Aims are Actualized in The National Primary Science curricula in China and Finland, International Journal of Science Education, 41(11), 1435-1456.

Yanni, M. L., \& Azizah, U. (2018). Pengembangan Lembar Kegiatan Siswa ( LKS) Berbasis Literasi Sains pada Materi Kesetimbangan Kimia Kelas XI, Unesa Journal of Chemical Education, 7(3), 308-314. 